\title{
Melon Seedlings Phytomass under Poultry Litter Biochar Doses
}

\author{
Laysa Gabryella de Souza Laurentino ${ }^{\mathbb{D}}$, Lúcia Helena Garófalo Chaves ${ }^{(1)}$, \\ Antônio Ramos Cavalcante ${ }^{(}$, Jean Pereira Guimarães ${ }^{(0)}$, Felipe Guedes de Souza $\left({ }^{\circ}\right.$, \\ Washington Benevenuto de Lima $\mathbb{(}^{\circ}$, Hugo Orlando Carvallo Guerra $\left.{ }^{(}\right)$, \\ Josely Dantas Fernandes $\mathbb{B}$
}

Department of Agricultural Engineering, Federal University of Campina Grande (DEAG/UFCG), Campina Grande, Brazil Email: laysaagabryella@live.com, ^lhgarofalo@hotmail.com, antoniosoledade@gmail.com, jean.p.guimaraes@gmail.com, felipeguedes.eng@gmail.com,washi_bene@yahoo.com.br,hugo_carvallo@hotmail.com, joselysolo@yahoo.com.br

How to cite this paper: de Souza Laurentino, L.G., Chaves, L.H.G., Cavalcante, A.R., Guimarães, J.P., de Souza, F.G., de Lima, W.B., Guerra, H.O.C. and Fernandes, J.D. (2021) Melon Seedlings Phytomass under Poultry Litter Biochar Doses. Agricultural Sciences, 12, 181-197. https://doi.org/10.4236/as.2021.123012

Received: February 2, 2021

Accepted: March 6, 2021

Published: March 9, 2021

Copyright ( 2021 by author(s) and Scientific Research Publishing Inc. This work is licensed under the Creative Commons Attribution International License (CC BY 4.0).

http://creativecommons.org/licenses/by/4.0/

\section{(c) (i) Open Access}

\begin{abstract}
The use of organic waste for the preparation of seedling substrates is an important environmental and economic option. In this perspective, substrates using biochar emerges as an alternative for seedling production due to their favorable physical and chemical characteristics. The present study aimed to evaluate the efficiency of doses of poultry litter biochar as a substrate constituent for the production and quality of the seedlings. The work was conducted in a semi protected environment, belonging to the Federal University of Campina Grande-UFCG. The statistical design used was completely randomized in a $6 \times 2$ factorial scheme, consisting of 6 doses of biochar $(0,4,8$, 12, 16 and $20 \mathrm{t} \cdot \mathrm{ha}^{-1}$ ) and two varieties of melon (Yellow and Hales Best Jumbo) with 4 repetitions totaling 48 experimental units. The fresh and dry plant phytomass mass (aerial, roots and total), root length and the quality of seedlings were evaluated. It was concluded that the addition of poultry litter biochar to the substrate was beneficial, promoting an increase in the analyzed seedling variables, being the ideal dose for good development of melon seedlings $12 \mathrm{t}^{\mathrm{h}} \mathrm{ha}^{-1}$. The Yellow variety presented a better response than the Hales Best Jumbo to the charcoal application. Considering the advantages of the use of poultry litter biochar on the substrate composition, found in the present study, its utilization constitutes a viable alternative for the development of melon seedlings and for the environmental disposal of the poultry litter.
\end{abstract}

\section{Keywords}

Biochar, Cucumis melo L., Nutrition, Alternative Substrate 


\section{Introduction}

The melon (Cucumis melo L.) is an oleracea of great national and international economic importance and although being an oleracea, in Brazil is commercialized as a fruit [1]. The melon is much appreciated, occupying in Brazil an area of 23.324 thousand ha with a fruit production of 581.478 thousand tons [2]. The Northeast is highlighted as a great production region, with the Rio Grande do Norte and Ceará states responsible by the biggest productions. The crop is concentrated in these regions mainly due to the favorable characteristics of the soil and climate of the semi-arid that influence positively the growth, development and productivity of the melon [3].

One of the main factors that influence the agronomic behavior of the oleracea is the seedlings' production [4] [5]. In general, the success of the seedlings production is the choose of a substrate that presents adequate physical and chemical characteristics, physical support [6] that furnishes the necessary nutrients for an adequate plant development [7]. The characteristic of the substrate influences highly the seedlings development, because provides beyond of physical support, nutritional supply until the transplant of them to the definitive production local [6]. Good quality seedlings will develop better and will provide a radicular system with better adaptation capability for the new local after transplant, affecting significatively the production [8].

In this context, the use of alternative materials for the composition of organic substrates has been tested. These materials besides of contribute to an ecological equilibrium, reducing the addition of chemical product to the soil, reduce also the cost of the substrate and therefore the seedlings production [9]. The materials constituting the organic substrate are usually easily obtained, mainly because are normally available in the same rural property or nearby locals, as crop or industrial residues [6].

Among the available alternative materials, it is found the biochar, a product derived by a pyrolysis process on which vegetal biomass with a high carbon content is decomposed in an atmosphere with absence of oxygen and temperatures varying between $350^{\circ} \mathrm{C}$ a $700^{\circ} \mathrm{C}$ [10]. The biochar, attends adequately the necessary requirements for seedlings production, where its benefits are related with its properties: high porosity, high water retention availability and high cationic exchange capacity. These properties favor the nutrients retention avoiding their losses, the direct nutrient furnishment and providing a habitat for benefic microorganisms that also can promote the nutrient liberation and the absorption by the plants [11].

The broiler production generates a significant amount of residues, highlighting the poultry litter [12], constituted by a mixture of excrements, feathers, rest of feeds and lignocelluloses materials that absorb humidity found on the poultry production floors [13]. Due to the high risks of negative environmental impacts caused by these residues, its utilization as a raw material for the production of 
biochar, can become an important alternative to minimize these impacts [14]. According to Jeffery et al. [15], the poultry litter biochar's proportionate the highest increase in growth and productivity of agricultural crops.

Chaves et al. [13] characterizing the poultry litter biochar for agricultural use inform that this material presents a considerable level of nutrients, mainly phosphorus and potassium, and a high cation exchange capacity, increasing thus the availability of these nutrients with positive impacts on crop production.

Pereira et al. [14] observed that ashes of poultry litter have higher concentration of phosphorus and potassium, essentials for the plant development, indicating thus that this material has a high potential for the biochar production.

Considering these facts and searching for a viable alternative for the production of more vigorous melon seedlings (Cucumis melo L.), the objective of the present work was to evaluate the response of the seedings to different doses of poultry litter biochar forming part of the substrate composition.

\section{Materials and Methods}

The experiment was carried out in a greenhouse at the Agricultural Engineering Department, Federal University of Campina Grande, Paraiba State, Brazil $\left(07^{\circ} 13^{\prime} 11^{\prime \prime S} ; 35^{\circ} 53^{\prime} 31^{\prime \prime W}\right)$ using soil collected at the $0-20 \mathrm{~cm}$ depth layer from the Agreste Region of Paraíba.

Soil samples characterized chemical and physically, according to Teixeira et al. [16], presented the following attributes: $\mathrm{pH}_{(\mathrm{H} 2 \mathrm{O})}=5.75 ; \mathrm{EC}_{\mathrm{se}}=0.16 \mathrm{dS} \cdot \mathrm{m}^{-1} ; \mathrm{Ca}=$ $1.56 \mathrm{cmol}_{c} \cdot \mathrm{kg}^{-1} ; \mathrm{Mg}=1.18 \mathrm{cmol}_{c} \cdot \mathrm{kg}^{-1} ; \mathrm{Na}=0.06 \mathrm{cmol}_{c} \cdot \mathrm{kg}^{-1} ; \mathrm{K}=0.26 \mathrm{cmol}_{\mathrm{c}} \cdot \mathrm{kg}^{-1}$; $\mathrm{H}=1.27 \mathrm{cmol}_{\mathrm{c}} \cdot \mathrm{kg}^{-1}$; organic matter $=14.8 \mathrm{~g} \cdot \mathrm{kg}^{-1} ; \mathrm{P}=4.9 \mathrm{mg} \cdot \mathrm{kg}^{-1} ;$ clay $=158.5$; silt $=120.7$ and sand $=720.8 \mathrm{~g} \cdot \mathrm{kg}^{-1}$.

The biochar utilized was generated throughout a pyrolysis process when poultry litter bed was submitted to a thermal decomposition at a temperature of $450^{\circ} \mathrm{C}$, in the absence of oxygen. After the production, biochar samples were placed in a dry oven and submitted to a temperature of $65^{\circ} \mathrm{C} \pm 5^{\circ} \mathrm{C}$, until constant weight, and analyzed chemically according to the Official Analytical Methods for Fertilizers and Correctives Handbook [17] recommended by the ASTM: D1762-84 [18] (2007) and developed for vegetal charcoal.

The biochar utilized had the following composition: $\mathrm{pH}_{(\mathrm{H} 2 \mathrm{O})}=9.45 ; \mathrm{N}=$ $3.45 \% ; \mathrm{P}=7.78 \% ; \mathrm{K}=4.90 \% ; \mathrm{Ca}=6.83 \% ; \mathrm{Mg}=1.34 \% ; \mathrm{S}=0.76 \% ; \mathrm{Fe}=0.46 \%$; $\mathrm{Cu}=0.04 \% ; \mathrm{Zn}=0.08 \% ; \mathrm{Mn}=0.09 \% ; \mathrm{B}=0.01 \%$; organic carbon $=39.77 \%$; organic matter $=68.56 \% ; \mathrm{C} / \mathrm{N}=11.53 \%$ and $\mathrm{CEC}=388.90 \mathrm{mmol}_{\mathrm{c}} / \mathrm{kg}$.

The experimental design used was a completely randomized factorial, with a 6 $\times 2$ scheme, consisting of six doses of biochar $(\mathrm{D} 0=0, \mathrm{D} 4=4, \mathrm{D} 8=8, \mathrm{D} 12=12$, $\mathrm{D} 16=16$, and D20 $\left.=20 \mathrm{t} \cdot \mathrm{ha}^{-1}\right)$ and two melon varieties $(\mathrm{V} 1=$ Yellow and V2 $=$ Hales Best Jumbo) with 4 replicates, totalizing 48 experimental units.

The experimental units consisted of plastic bags $(15 \times 28 \mathrm{~cm})$ with holes on their bottom for water drainage, filled with dried soil, biochar and vermiculite and sieved on a $2 \mathrm{~mm}$ mesh sieve. These substrates consisted of a mixture of soil 
and vermiculite in a $1: 10$ ratio, and the increasing doses of biochar $(0 ; 10 ; 20 ; 30$; 40 and 50 grams of biochar per $\mathrm{kg}$ of soil). Afterwards they were left in incubation for a period of 90 days keeping the substrates moisture close to the field capacity. The addition of vermiculite in the experimental units aimed to make the soil less dense and compacted, as well as airier. After the incubation period, substrate samples were collected from the experimental units, air-dried, grounded, sieved with a $2 \mathrm{~mm}$ mesh and analyzed according to the methodology proposed by [16].

Sowing was carried out by placing in each experimental unit four seeds distributed equidistantly at $2 \mathrm{~cm}$ soil depth, and after fourteen days plants thinning was conducted keeping the most vigorous plant in each experimental unit.

Manual irrigation was carried out daily in order to keep the soil to the field capacity aiming the best germination of the seeds, the emergence of seedlings and plant development. Undesired plants that appeared in the experimental units during the experiment were eliminated manually. No mineral fertilization was used in the experiment.

Thirty-one days after sowing (DAS), the seedlings were collected evaluating the fresh phytomass of the leaf (FLP), of the stem (FSP), of the aerial part of the plant (FAP), of the root (FRP) and of the total phytomass (FTP). Also were evaluated the dry phytomass of the leaf (DLP), of the stem (DSP), of the aerial part of the plant (DAP), of the root (DRP) and of the total phytomass (DTP). Finally, the root length and the Quality Index of Dickson (DQI) were evaluated.

The fresh phytomass was determined sectioning the plants in leaves, stem and roots and weighed in an analytical balance. The roots were carefully retired, washed and measured their length. The dry phytomass was determined washing the fresh harvested plant material with deionized water and dried on an oven with forced ventilation at $65^{\circ} \mathrm{C}$ until a constant weight was achieved.

The Quality Index of Dickson (DQI), which considers the equilibrium of the most important plant biomass components evaluated, such as plant height, stem diameter and biomass [19] was obtained by using the Equation (1) [20]:

$$
\mathrm{DQI}=\frac{\mathrm{TDP}}{\frac{\mathrm{PH}}{\mathrm{SD}}+\frac{\mathrm{ADP}}{\mathrm{RDP}}}
$$

where: DQI = Quality Index of Dickson; TDF = Total dry phytomass $\left(\right.$ g.planta $\left.{ }^{-1}\right)$; ADP Aerial dry phytomass $\left(\mathrm{g} \cdot\right.$ planta $\left.^{-1}\right) ; \mathrm{RDP}=$ Root dry phytomass $\left(\right.$ g planta $^{-1}$ ); $\mathrm{PH}=$ plant height $(\mathrm{cm})$ and $\mathrm{SD}=$ stem diameter $(\mathrm{mm})$.

Plant height $(\mathrm{PH})$ in $\mathrm{cm}$, was measured with a tape and the stem diameter (SD) in $\mathrm{mm}$, with the aid of a digital caliper, placing it on the plant's neck. Plant height and stem diameter information was obtained from research in press.

The results obtained were submitted to the homogeneity (Cochran and Bartlett), and to the normality test (Shapiro-Wilk). With the exception of the root length and the aerial dry phytomass, the other parameters were submitted to the analysis of variance by the $\mathrm{F}$ test at 1 and $5 \%$ probability. When there was significant effect for these, polynomial regression analysis was used for biochar doses. 
Comparison between melon varieties conducted by using the T-student test ( $\mathrm{p}$-value or $\mathrm{p}<0.05$, is the level of confidence).

To attend normality for the variables FLP, FSP, FRP e FTP, they were transformed in $\frac{x^{1.7929}-1}{1.7929} ; \frac{x^{0.9848}-1}{0.9848} ; \sqrt{x}$ and $\frac{x^{0.3787}-1}{0.3787}$, respectively. The root length (RL) and aerial dry phytomass data (DAP), which did not reach the requirements of normality for the ANOVA tests, were analyzed utilizing the Kruskal and Wallis non-parametric statistical method [21].

\section{Results and Discussion}

After applying biochar to the soils and incubating for 90 days, the poultry litter biochar doses affected significantly influenced all chemical properties of the soil (Table 1).

Soil $\mathrm{pH}$ values increased in a quadratic way after the addition of the biochar where the highest $\mathrm{pH}$ value was 7.55 with the $17.18 \mathrm{t} \cdot \mathrm{ha}^{-1}$ dose (Figure 1(a)), producing an increase of $25 \%$, with respect to the 0 dose. This increase was expected since the $\mathrm{pH}$ of the poultry litter biochar was 9.45. According to Sparks [22], changes in soil $\mathrm{pH}$ occur when cations from biochar remove aluminum (Al) from the clay and/or organic matter exchange sites reacting it with soluble monomeric $\mathrm{Al}$ species, or due the subsequent dissolution of hydroxides and carbonates [23]. Therefore, the biochar acts as a soil acidity corrector.

The Electrical Conductivity (EC) of the substrate increased linearly with the biochar reaching a value of $1.45 \mathrm{dS} \cdot \mathrm{m}^{-1}$ for the $20 \mathrm{t} \cdot \mathrm{ha}^{-1}$ dose (Figure $1(\mathrm{~b})$ ). The results agree with [24] who also working with poultry litter biochar doses observed an increase of the EC, with the biochar application reaching a value of $0.39 \mathrm{dS} \cdot \mathrm{m}^{-1}$ with the $30 \mathrm{t} \cdot \mathrm{ha}^{-1}$ dose. The increase of the EC of the substrate with the biochar is related with the increase of the exchangeable bases of potassium calcium, magnesium and sodium, available in the biochar, as will be commented afterwards.

Table 1. Analysis of variance for the $\mathrm{pH}$, electrical conductivity (EC), calcium $\mathrm{Ca})$, magnesium (Mg), sodium (Na), potassium (K), organic matter $(\mathrm{OM})$, organic carbon $(\mathrm{C})$ and phosphorus $(\mathrm{P})$ in the substrate as influenced by the biochar doses.

\begin{tabular}{|c|c|c|c|c|c|c|c|c|c|c|}
\hline \multirow{2}{*}{$\begin{array}{l}\text { Source of } \\
\text { Variation }\end{array}$} & \multirow{2}{*}{$\mathrm{DF}$} & \multicolumn{9}{|c|}{ Mean Square } \\
\hline & & $\mathrm{pH}$ & $\mathrm{EC}$ & $\mathrm{Ca}^{1}$ & $\mathrm{Mg}$ & $\mathrm{Na}$ & K & $\mathrm{OM}$ & $\mathrm{C}$ & $\mathrm{P}$ \\
\hline Biochar Doses & 5 & $1.45^{\star *}$ & $0.45^{\star *}$ & $0.057^{\star}$ & $11.92^{*}$ & $0.55^{\star *}$ & $9.80^{* *}$ & $309.57^{\star *}$ & $104.16^{* *}$ & $55101.73^{*}$ \\
\hline Linear & 1 & $6.12^{\star \star}$ & $2.10^{\star *}$ & $0.028^{*}$ & $14.86^{\star *}$ & $2.74^{\star *}$ & $47.61^{\star *}$ & $1499.1^{\star *}$ & $504.40^{\star *}$ & $150709.5^{\star *}$ \\
\hline Quadratic & 1 & $0.98^{\star \star}$ & $0.01^{\mathrm{ns}}$ & $0.099^{\star *}$ & $32.43^{\star *}$ & $0.006^{\text {ns }}$ & $0.38^{\star *}$ & $13.8^{\mathrm{ns}}$ & $4.64^{\mathrm{ns}}$ & $120797.1^{* *}$ \\
\hline Desvio & 3 & $0.04^{\star}$ & $0.05^{\star *}$ & $0.053^{* *}$ & $4.10^{\mathrm{ns}}$ & $0.010^{\text {ns }}$ & $0.33^{* *}$ & $11.6^{\mathrm{ns}}$ & $3.91^{\mathrm{ns}}$ & $1333.9^{\text {ns }}$ \\
\hline Error & 18 & 0.009 & 0.008 & 0.006 & 1.37 & 0.01 & 0.02 & 6.94 & 2.33 & 6696.06 \\
\hline $\mathrm{CV}(\%)$ & & 1.41 & 8.84 & 12.56 & 13.74 & 9.19 & 5.49 & 9.04 & 9.04 & 37.43 \\
\hline Mean & & 7.06 & 1.02 & 0.60 & 8.53 & 1.12 & 2.51 & 29.14 & 16.90 & 218.61 \\
\hline
\end{tabular}

DF: Degree of Freedom; ${ }^{*}$ and ${ }^{* *}$ : significant $(0.05 \leq \mathrm{p})$ and $(0.01 \leq \mathrm{p})$ probability of error. ${ }^{\text {ns}}$ : not significant; CV: Coefficient of Variation; ${ }^{1}=$ data transformed into $1 / \sqrt{x}$. 


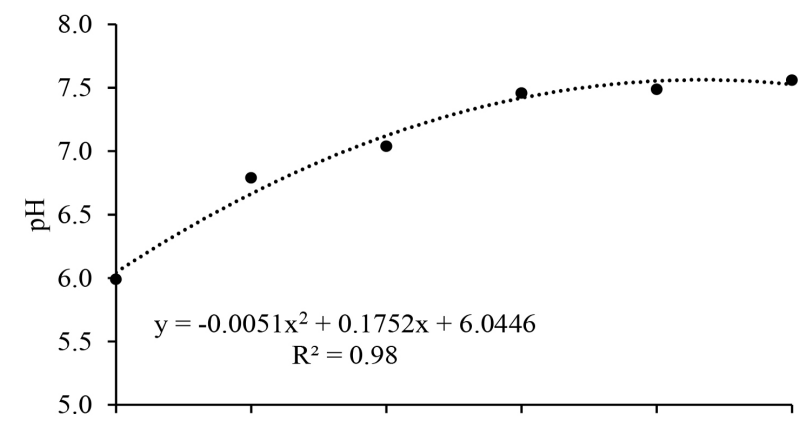

(a)

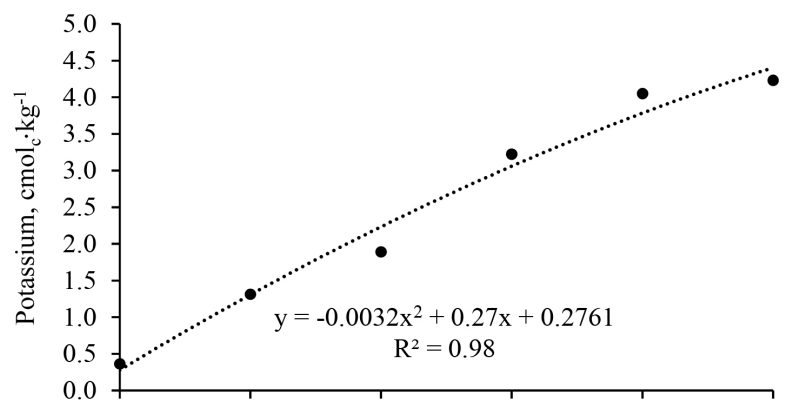

(c)

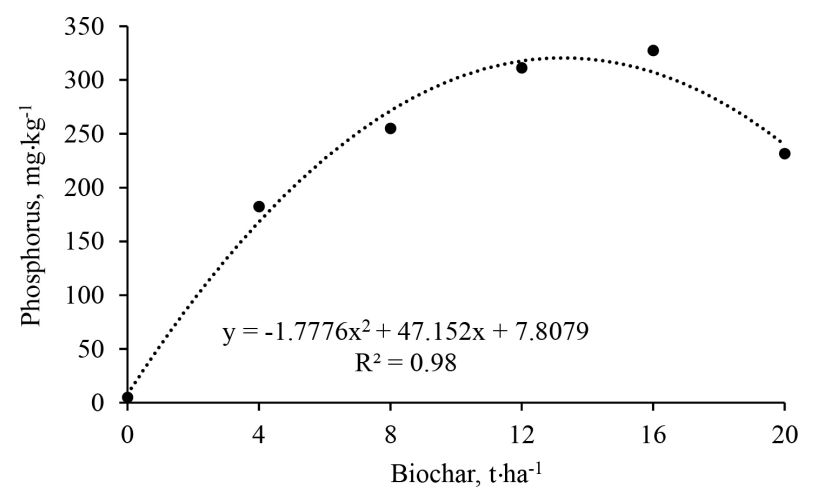

(e)

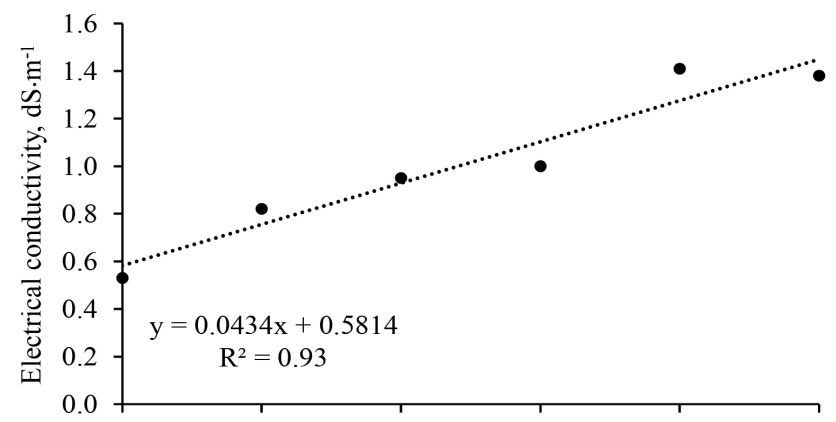

(b)

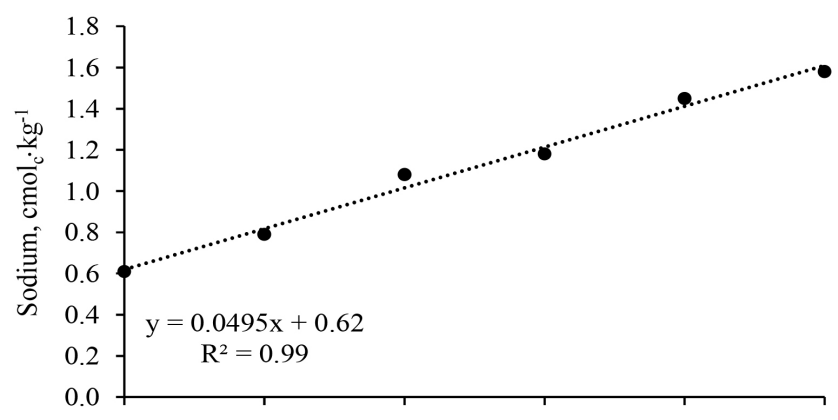

(d)

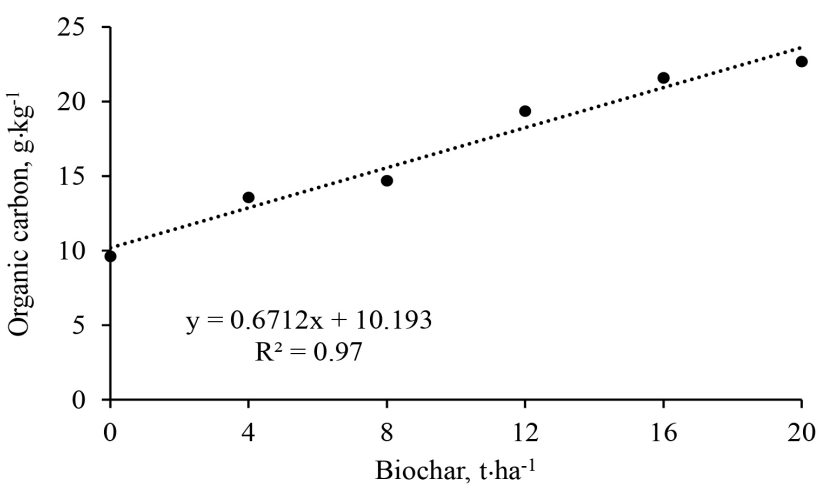

(f)

Figure 1. pH (a), electrical conductivity (b), potassium (c), sodium (d), phosphorus (e) and organic carbon (f) after incubation period for the biochar treatments.

Ayers and Westcot [25] indicate that substrates with an Electrical Conductivity over $1 \mathrm{dS} \cdot \mathrm{m}^{-1}$ prejudice most of the plants sensible to salinity conditions. In the present study, the substrates that received more than $10 \mathrm{t} \cdot \mathrm{ha}^{-1}$ and presented CE values over $1 \mathrm{dS} \cdot \mathrm{m}^{-1}$ prejudicated the melon seedlings behavior. Silva et al. [26] utilizing poultry litter biochar in substrates with arugula obtained an electrical conductivity of $3.05 \mathrm{dS} \cdot \mathrm{m}^{-1}$ observed elevated concentrations of potassium and phosphorus in the substrate, and low dry phytomass of the aerial, root and total part of the plant, results similar to the ones obtained in the present work. 
Equal results were also reported by [27] working with lemon rootstocks.

The exchangeable cations content (potassium and sodium) increased with poultry litter biochar concentrations in a quadratic and linear form, respectively, which is in accordance with previous studies [24] [28] [29]. According to Figure 1 (c) and Figure $1(\mathrm{~d})$, the concentrations of potassium and sodium, 4.40 $\mathrm{cmol}_{\mathrm{c}} \cdot \mathrm{kg}^{-1}$ and $1.61 \mathrm{cmol}_{\mathrm{c}} \cdot \mathrm{kg}^{-1}$, were obtained with the highest dose of biochar $\left(20 \mathrm{t}^{2} \mathrm{a}^{-1}\right)$, with an increase of around $1492 \%$ and $160 \%$, between these values and the control, respectively. These data are similar to the $1754 \%$ and $151 \%$, found by [29], evaluating an increase in the levels of potassium and sodium in soil with application of the same biochar. The release of these elements in the soil influences the growth of plants, as occurred in the present research in relation to the development of seedlings (Figure 2 and Figure 3 ).

The available phosphorus increased with the biochar obtaining the highest concentration $\left(312.68 \mathrm{mg} \cdot \mathrm{dm}^{-3}\right.$ ) with the dose of $13.26 \mathrm{t} \cdot \mathrm{ha}^{-1}$ of biochar (Figure $1(\mathrm{e}))$, i.e., there were increased of $3905 \%$ in relation to control, corroborating [29] who observed a 5131\% increase in her experiment. This high significantly increase is probably due to the presence of potassium phosphate in the biochar composition, or because biochar of chicken manure in the soil increase mycorrhizal colonization and the availability of phosphorus $\mathrm{P}$ in the soil.

According to Bohara et al. [30] biochar changes the relative distribution of phosphorus species in the soil in a beneficial way increasing their availability for crops. Therefore, this fact probably influenced significantly the seedling production variables as will be shown in Figure 2 and Figure 3.

The content of soil organic carbon increased linearly with biochar concentrations (Figure 1(f)). This is probably because biochar also undergoes biodegradation, although it is considered stable in the soil system [28].

Observing the variance analyses for the melon seedlings variables studied (Table 2), it was observed high significant effects of the applied doses of biochar on the isolated factors as much of their interactions.

The variance analyses for the fresh leaf phytomass (FLP), for the stem (FSP), for the aerial part of the plant (FAP) and for the total fresh phytomass (FTP) of the Hales Best Jumbo variety showed high significant effects of the biochar doses on the variables studied, however, as the coefficients of determination $\left(\mathrm{R}^{2}\right)$ were very low for quadratic regressions, $0.19 ; 0.35 ; 0.30 ; 0.41$, respectively, do not represent their behavior. Therefore, these regressions are not discussed.

With respect to the fresh leaf phytomass (FLP) (Figure 2(a)), the results were adjusted to a quadratic model where the Yellow variety (V1) obtaining a FLP of $149.52 \mathrm{~g}$ (22.66 g, not transformed data) with the biochar dose of $10.38 \mathrm{t} \cdot \mathrm{ha}^{-1}$. Petter et al. [31] (2012a), evaluating the potential of wood biochar for the production of eucalyptus seedlings utilizing 5 biochar concentrations added to a commercial substrate, observed that the best results were obtained in the substrates with $7.5 \%$ of biochar, thus as in the present work, lower concentration of biochar produced better production. 
Table 2. Analyzes of variance for the fresh leaf phytomass (FLP), for the stem (FSP), for the aerial part of the plant (FAP), for the root (FRP) and for the total fresh phytomass (FTP) of the melon varieties submitted to biochar doses.

\begin{tabular}{cccccc}
\hline \multirow{2}{*}{ Source of variation } & \multicolumn{5}{c}{ Mean square } \\
\cline { 2 - 6 } & FLP & FSP & FAP & FRP & FTP \\
\hline Biochar dose (D) & $13,422.03^{* *}$ & $55.18^{* *}$ & $383.75^{* *}$ & $37.17^{* *}$ & $643.12^{* *}$ \\
Melon Variety (V) & $3482.63^{* *}$ & $48.18^{* *}$ & $0.07^{\text {ns }}$ & $0.02^{\text {ns }}$ & $0.01^{\text {ns }}$ \\
D x V & $5612.92^{* *}$ & $17.54^{* *}$ & $118.42^{* *}$ & $4.58^{\text {ns }}$ & $166.99^{* *}$ \\
Dose within V1 & & & & & \\
Linear & $801.0^{*}$ & $2.91^{\text {ns }}$ & $32.99^{* *}$ & - & $100.92^{* *}$ \\
Quadratic & $4702.2^{* *}$ & $186.75^{* *}$ & $1426.42^{* *}$ & - & $2316.03^{* *}$ \\
Deviation & $1767.7^{* *}$ & $26.43^{* *}$ & $48.23^{* *}$ & - & $71.34^{* *}$ \\
Dose within V2 & & & & & \\
Linear & $1637.5^{* *}$ & $19.07^{* *}$ & $106.91^{* *}$ & - & $198.35^{* *}$ \\
Quadratic & $6549.2^{* *}$ & $14.35^{* *}$ & $164.06^{* *}$ & - & $377.25^{* *}$ \\
Deviation & $11,285.1^{* *}$ & $20.41^{* *}$ & $211.92^{* *}$ & - & $281.33^{* *}$ \\
Residue & 128.26 & 48.498 & 3.74 & 2.12 & 7.92 \\
Variation Coefficient & 10.67 & 10.58 & 6.63 & 34.86 & 8.44 \\
Mean & 106.11 & 10.97 & 29.17 & 4.18 & 33.35 \\
\hline$* * *$ & & & & & \\
\hline
\end{tabular}

${ }^{*},{ }^{* *}$ significant to the 0.05 and 0.01 probability, respectively, ${ }^{\text {ns }}$ not significant.

For the fresh stem phytomass, FSP (Figure 2(b)), the data was adjusted to a quadratic model with a maximum value of $15.24 \mathrm{~g}$ with the biochar dose of 10.36 t.ha ${ }^{-1}$ for the Yellow variety.

Evaluating the significant interaction effect of the biochar doses for the FAP of the Yellow variety (Figure 2(c)) it was observed that the results were adjusted to a quadratic model with the highest production of $38.26 \mathrm{~g}$ for the dose of 10.44 t.ha ${ }^{-1}$. Galvão et al. [32] evaluating the behavior of chicory seeedlings (Eryngium foetidum L.) when submitted to chemical and organic fertilization associated to biochar, observed positive results with an aerial fresh phytomass of 0.48 g.planta ${ }^{-1}$ when compared to the witness with only $0.26 \mathrm{~g} \cdot$ planta $^{-1}$, a production $85 \%$ higher. The fresh phytomass of the root (FRP) was affected significantly by the biochar doses following a quadratic model with a maximum production of $6.29 \mathrm{~g}$ with the estimated biochar doses of $11.38 \mathrm{t} \cdot \mathrm{ha}^{-1}$, decreasing with further increase of biochar (Figure 2(d)). Evaluating the effect of the addition of eucalyptus sawdust biochar on the lettuce fresh phytomass of the root, Silva et al. [33] also observed a quadratic tendence obtaining the maximum FRP with the substrate containing $5 \%$ of biochar. 


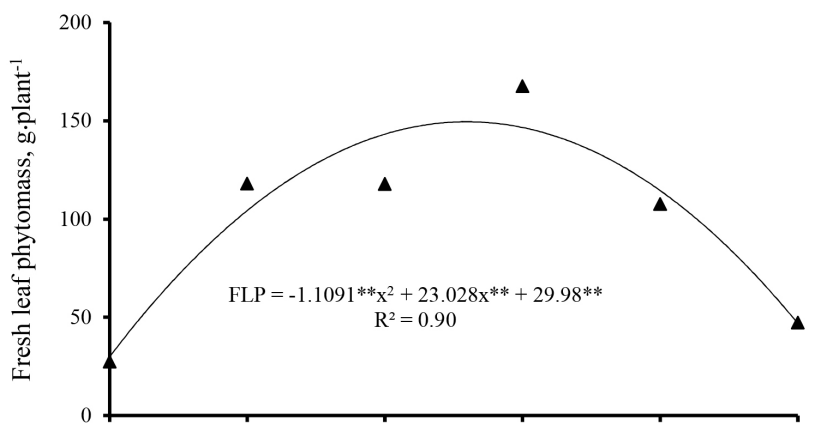

(a)

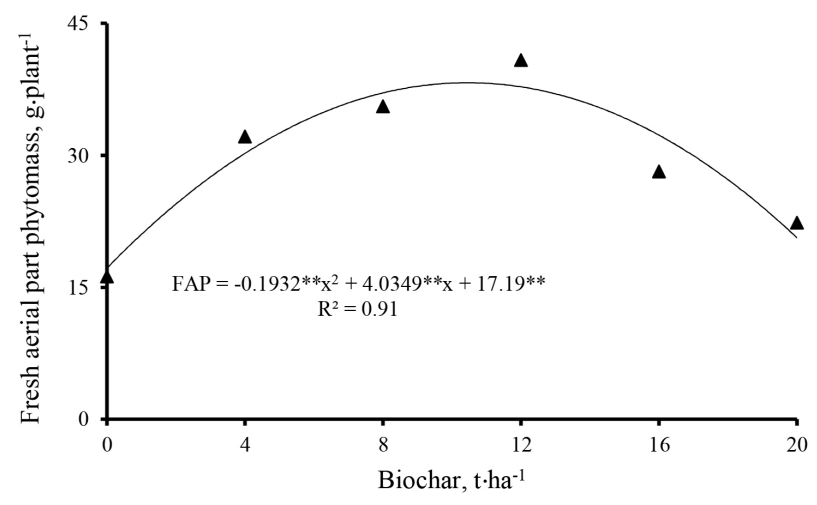

(c)

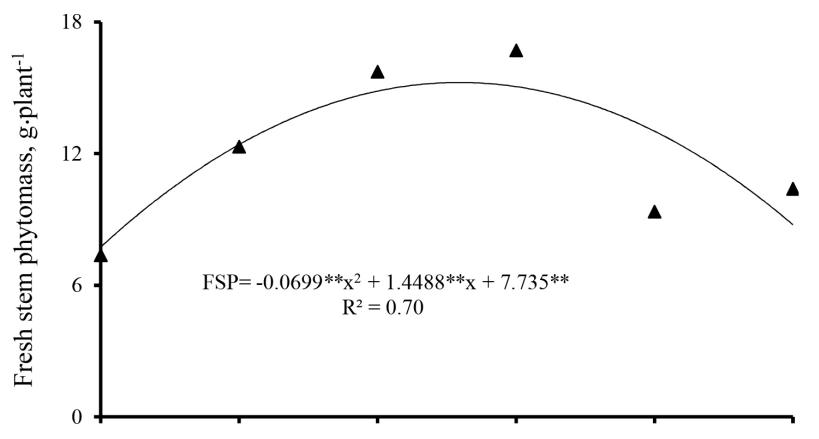

(b)

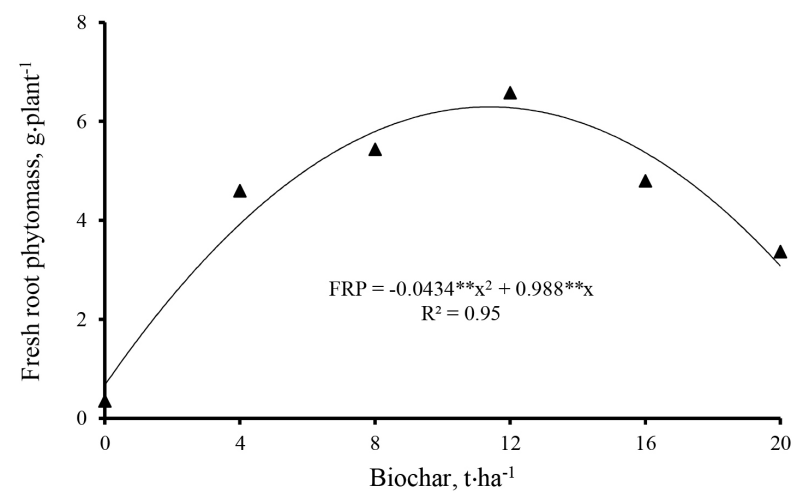

(d)

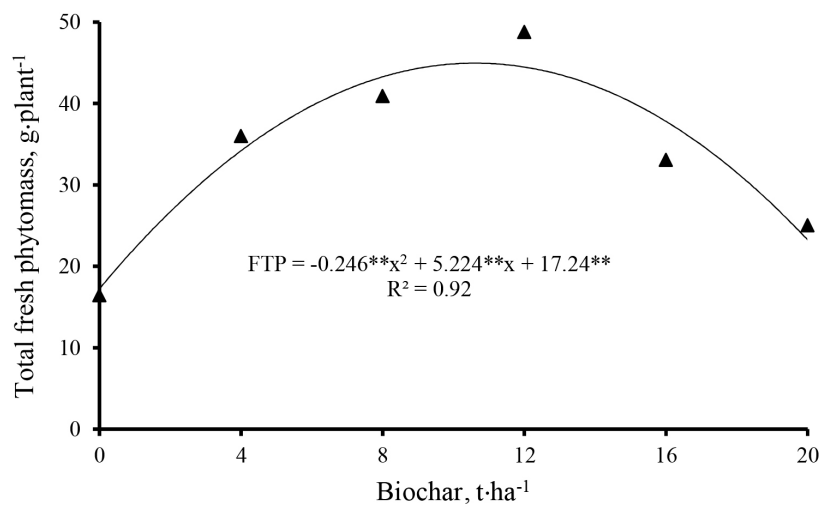

(e)

Figure 2. Fresh phytomass of the leaf (FLP) (a), for the stem (FSP) (b), for the aerial part of the plant (FAP) (c), for the root (FRP) (d) and for the total phytomass (FTP) (e) of the Yellow melon variety. Means followed by the same letter do not differ.

Evaluating the significant interaction effect of the biochar doses on the fresh total phytomass (Figure 2(e)) it was verified that the data was adjusted to a quadratic model with a maximum production of $44.97 \mathrm{~g}$ with the dose of 10.62 t.ha ${ }^{-1}$, for the Yellow variety. The high FTP observed with the biochar application demonstrate a good performance of the melon seedlings at biochar application, fact probably due to the high nutrient availability that the biochar produces [30] mainly due to the presence of reactive surfaces of the aromatized structures in the biochar pores [34]. 
The biochar doses affected significatively all the dry phytomass evaluated. The melon varieties affected only the dry stem phytomass (DSP) and the Dickson quality index (DQI). The biochar doses $\mathrm{x}$ melon variety affected the DLP, the DRP, the DTP and also the DQI (Table 3).

The biochar doses $\mathrm{x}$ varieties interaction influenced significatively the dry leaf phytomass (Figure 3(a)) presenting a quadratic adjust just for the Yellow variety (V1) with a maximum phytomass of $1.26 \mathrm{~g}$ ( $2.27 \mathrm{~g}$ not transformed) for the dose of $8.82 \mathrm{t} \cdot \mathrm{ha}^{-1}$.

Analyzing the dry stem phytomass (DSP) as affected by the biochar doses (Figure 3(b)), it was observed that the data was adjusted to a quadratic model with the highest phytomass $(0.98 \mathrm{~g})$ obtained with the biochar dose of 10.06 t.ha ${ }^{-1}$. For the dry root phytomass (DRP) it is possible to observe a quadratic performance for both varieties with a maximum of $1.57 \mathrm{~g}$ (2.46 $\mathrm{g}$ - not transformed) for the dose of $10.71 \mathrm{t} \cdot \mathrm{ha}^{-1}$ for the Yellow variety and $1.34 \mathrm{~g}$ (1.39 $\mathrm{g}$-not transformed) for the dose of $12.04 \mathrm{t} \cdot \mathrm{ha}^{-1}$ for the Hales Best Jumbo (Figure 3(c)). Working with Tachigali vulgaris, Souchie et al. [35] verified that the application of eucalyptus wood biochar to the substrate started to be significative important for the dry root phytomass after the application of a volume equal to the $12.5 \%$ of the total volume of the substrate.

Table 3. Analyzes of variance for the dry leaf phytomass (DLP), dry stem phytomass (DSP), dry root phytomass (DRP), dry total phytomass (DTP) and for the Dickson quality index (DQI) for the melon varieties submitted to biochar doses.

\begin{tabular}{|c|c|c|c|c|c|}
\hline & \multicolumn{5}{|c|}{ Mean Square } \\
\hline & DLP & DSP & DRP & DTP & DQI \\
\hline Biochar doses (D) & $1.06^{\star *}$ & $0.61^{\star \star}$ & $1.6^{* *}$ & $3.10^{* *}$ & $0.133^{\star \star}$ \\
\hline Melon variety $(\mathrm{V})$ & $0.06^{\mathrm{ns}}$ & $0.73^{\star *}$ & $0.0005^{\mathrm{ns}}$ & $0.01^{\mathrm{ns}}$ & $0.068^{* x}$ \\
\hline $\mathrm{D} x \mathrm{~V}$ Interaction & $0.42^{\star}$ & $0.06^{\mathrm{ns}}$ & $0.28^{\star \star}$ & $0.74^{\star *}$ & $0.025^{\star}$ \\
\hline \multicolumn{6}{|l|}{ Dose within V1 } \\
\hline Linear & $0.52^{\mathrm{ns}}$ & - & $0.36^{*}$ & $9.00 e^{-6 n s}$ & $0.006^{\mathrm{ns}}$ \\
\hline Quadratic & $3.33^{* *}$ & - & $4.60^{\star *}$ & $11.59^{* *}$ & $0.31^{\star *}$ \\
\hline Deviation & $0.20^{\mathrm{ns}}$ & - & $0.25^{\star \star}$ & $0.38^{*}$ & $0.04^{\star *}$ \\
\hline \multicolumn{6}{|l|}{ Dose within V2 } \\
\hline Linear & $0.01^{\mathrm{ns}}$ & - & $0.63^{* *}$ & $0.703^{*}$ & $0.02^{\text {ns }}$ \\
\hline Quadratic & $0.90^{\mathrm{ns}}$ & - & $1.17^{\star *}$ & $2.085^{\star *}$ & $0.19^{\star *}$ \\
\hline Deviation & $0.93^{\star *}$ & - & $0.37^{\star \star}$ & $1.250^{* *}$ & $0.03^{*}$ \\
\hline Resídue & 0.13 & 0.027 & 0.05 & 0.11 & 0.009 \\
\hline VariationCoefficient & 44.11 & 22.05 & 20.98 & 20.02 & 34.08 \\
\hline Mean & 0.85 & 0.50 & 1.06 & 1.71 & 0.29 \\
\hline
\end{tabular}

${ }^{*},{ }^{* *}$ significant to the 0.05 and 0.01 probability, respectively, ${ }^{\text {ns }}$ not significant. 


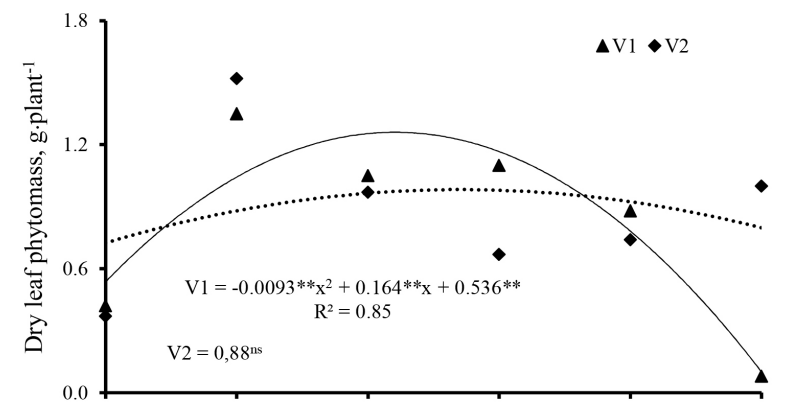

(a)

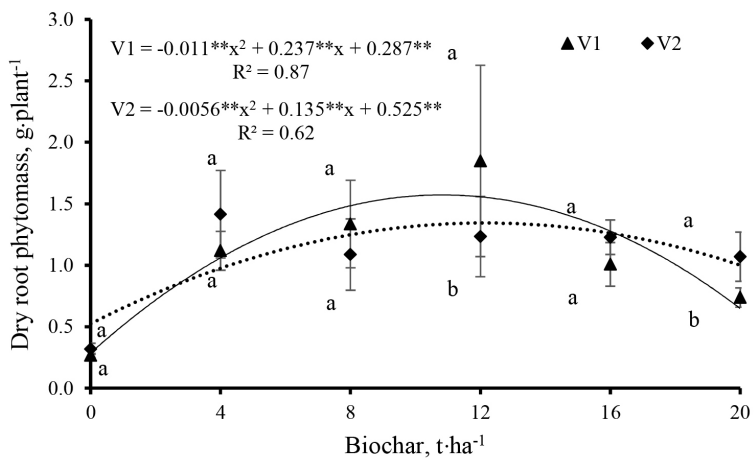

(c)

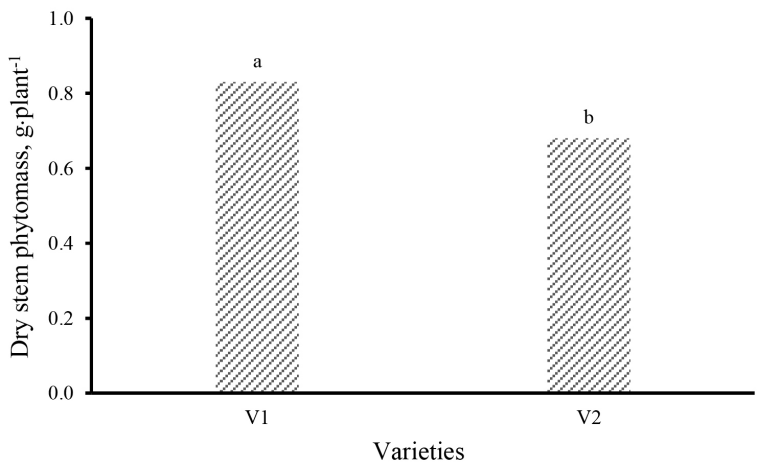

(e)

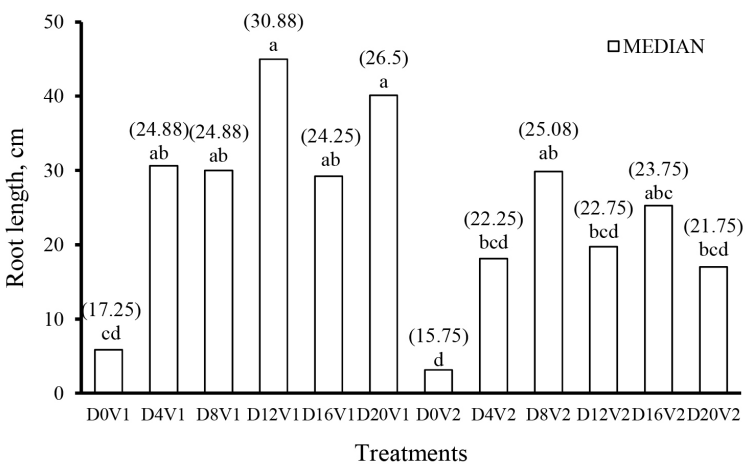

(g)

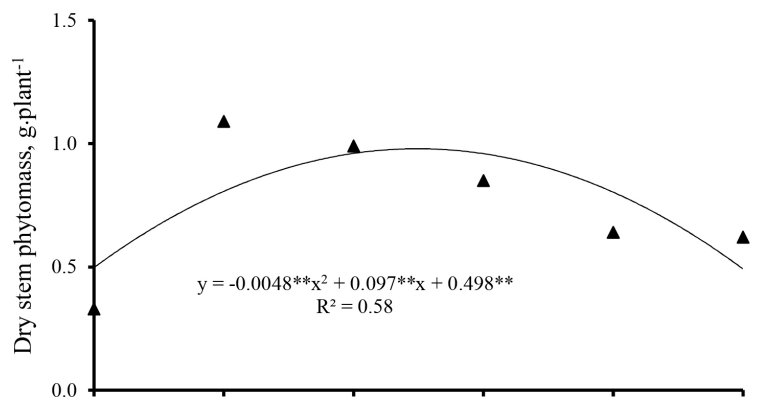

(b)

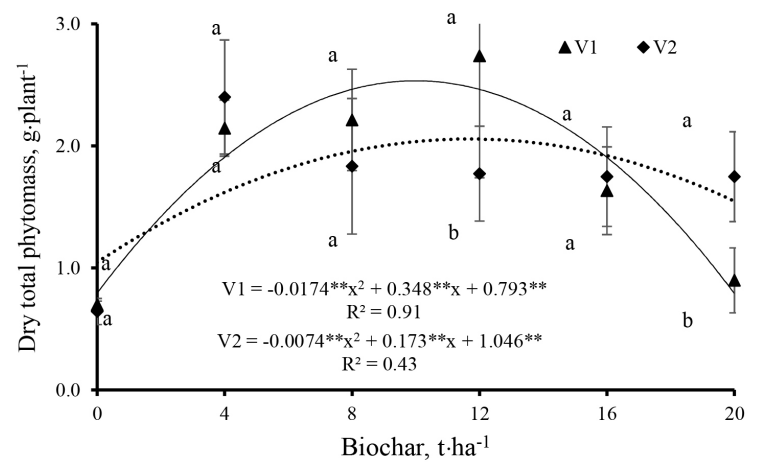

(d)

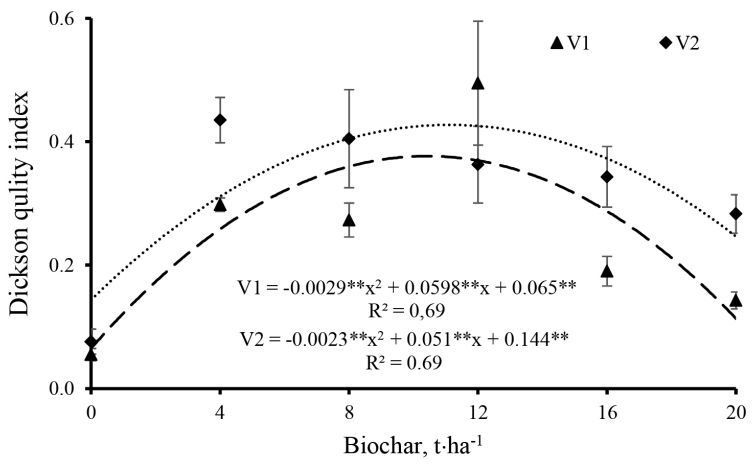

(f)

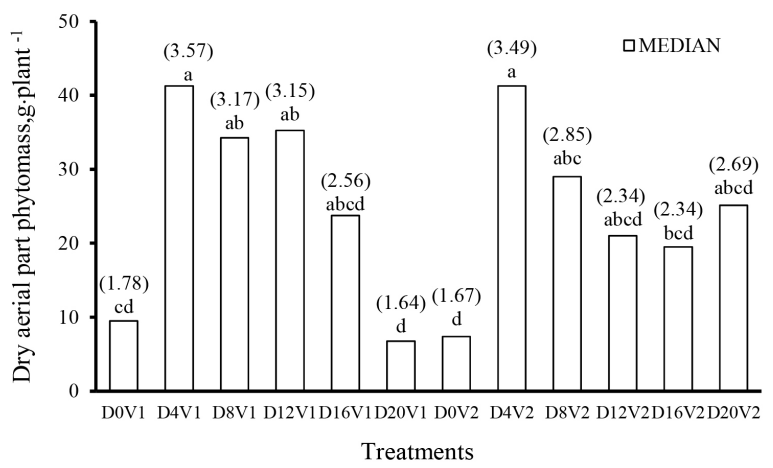

(h)

Figure 3. Effects of the biochar doses for the dry leaf phytomass (a), dry stem phytomass (b), dry root phytomass (c), dry total phytomass (d); effects of the varieties for the dry stem phytomass (e); effects of the treatments for the root length (g), for dry aerial part phytomass ( $\mathrm{h}$ ) and for the Dickson quality index (f). (V1 = Yellow, V2 = Hales Best Jumbo). Means followed by the same letter do not differ. 
It was also observed a significative effect of the dry total phytomass and a quadratic performance for both varieties with a maximum of $2.53 \mathrm{~g}$ ( $5.89 \mathrm{~g}$ - not transformed) for the dose of $10.01 \mathrm{t}^{\mathrm{h}} \mathrm{ha}^{-1}$ for the Yellow variety and $2.06 \mathrm{~g}(4.58$ $\mathrm{g}$-not transformed) for the dose of $11.68 \mathrm{t} \cdot \mathrm{ha}^{-1}$ for the Hales Best Jumbo (Figure 3(d)). The dry total phytomass is normally used to express the productivity of the plant [36]. The optimum biochar doses for both varieties, found on the present work, are similar to the $11.39 \mathrm{~g}$ found by [37] who evaluated the effect of different doses of vegetal charcoal $(0 \%, 10 \%, 30 \%, 50 \%$ and $70 \%$ in volume of charcoal per soil volume) on the seedlings production of Brazilian chestnuts (Bertholletia excelsa H. B. K).

Analyzing the effect of the varieties (Figure $3(\mathrm{e})$ ), the best results were obtained with the Yellow variety $(0.83 \mathrm{~g}), 22.06 \%$ bigger than the one obtained for the Hales Best Jumbo (0.68 g).

The root length for both melon varieties were also analyzed utilizing the Kruskal and Wallis, non-parametric method [21] (Figure 3(g)), It was observed that the Yellow variety responded better that the Hales Best Jumbo with the biochar application. The higher values of the Yellow variety, when the substrate was fertilized with 12 and $20 \mathrm{t}^{-h^{-1}}$ of biochar were of 26.5 to $30.88 \mathrm{~cm}$, and for the Hales Best Jumbo of 23.75 to $25.8 \mathrm{~cm}$ with an application of 8 and $16 \mathrm{t} \cdot \mathrm{ha}^{-1}$ of biochar (not transformed data).

Mendes et al. [38] studying the effect of different substrates (coconut fiber, worm humus, vermiculite and sieved carnauba rests) found that the physical characteristics of the used substrates influenced the root growth, indicating that the substrate that proportionated the bigger aeration and water retention produced the better root formation of the carnauba seedlings. Zanetti et al. [27] confirm this, indicating that the biochar application increase porosity and aeration improving the root exploration. Melo et al. [39] add that a greater root development is very important for the plant growth, considering that well developed roots can provide a greater water and nutrients absorption. Hermann [40] indicates that the dry root phytomass is one of the most important parameters for the establishment and survival of the seedlings in the field, because the roots are totally associated with the physiological characteristics of the seedlings.

When the dry aerial phytomass data (Figure $3(\mathrm{~h})$ ) was analyzed by the Kruskal and Wallis, non-parametric method [21] it was observed the higher values of the Yellow variety, when the substrate was fertilized with $4 \mathrm{t} \cdot \mathrm{ha}^{-1}$ of biochar obtaining a dry phytomass of $3.57 \mathrm{~g} \cdot$ plant $^{-1}$, and a phytomass for the Hales Best Jumbo of $3.494 \mathrm{t} \cdot \mathrm{ha}^{-1}$ with an application of a doses $4 \mathrm{t} \cdot \mathrm{ha}^{-1}$ of biochar, decreasing with higher doses. Souza et al. [41] comparing the poultry bed biochar with the Plantmax ${ }^{\otimes}$ commercial substrate indicate that considering the dry aerial phytomass and the low cost of the first product it can efficiently substitutes the commercial one.

Silva et al. [28] studying the use of rice bark biochar, saw dust and sorghum silage rests observed that the biochar concentration of $2.5 \%, 5 \%$ and $7.5 \% \mathrm{v} / \mathrm{v}$ 
incremented the dry root, the dry aerial and the dry total plant phytomass.

The results found in the present work are probably related to the high nutrient concentration of the biochar. The organic matter accumulation and nutrient availability, such as phosphorus and potassium, furnished by the biochar application are related to a formation of carbon skeletons in the substrate structure, which permit a satisfactory development of the plants [42] [43].

The biochar doses $\mathrm{x}$ variety interaction influenced significatively the Dickson Quality Index (Figure 3(f)), varying from 0.049 to 0.055 for the Yellow variety (V1) and 0.435 to 0.076 for the Hales Best Jumbo (V2) adjusting both of them to a quadratic model. For the V1 variety the highest DQI was 0.37 with $10.31 \mathrm{t} \cdot \mathrm{ha}^{-1}$ and 0.43 for V2 with $11.09 \mathrm{t}^{\mathrm{h}} \mathrm{ha}^{-1}$. Considering that the minimum DQI recommended by Hunt [44] is 0.20 , the values found in the present study for this index indicate that the melon seedlings are of high quality and appropriated for the transplanting to the definitive local. A large Dickson Quality Index (DQI) value indicates a more desirable phenotype and the greater the DQI, the better the seedlings vigor (SV), indicating robustness and balance in the distribution of biomass in the seedling [45].

Melo et al. [39] observed that the highest values of dry phytomass (leaves, stem and roots) and root length of the guabiroba were related to the highest $\mathrm{Ca}$ and $\mathrm{Mg}$ concentrations of the substrate and with the $\mathrm{N}, \mathrm{P}, \mathrm{K}$ and $\mathrm{S}$ availability due to the increase of the substrate $\mathrm{pH}$. The $\mathrm{pH}$ variation of the substrates found in the present study (Table 1) are within the adequate interval for the melon plant, which behave better between 6.0 to 7.5 , no influencing the nutrient availability.

\section{Conclusions}

In a bid to enhance to produce seedlings of better quality using alternative materials for the composition of organic substrates, this study evaluated the response of these seedlings to different doses of poultry litter biochar.

The fresh and dry phytomass of the melon and the quality of the melon seedlings increased with the poultry litter biochar doses utilized on the substrate.

The application of $12 \mathrm{t} \cdot \mathrm{ha}^{-1}$ of biochar produced the best development, phytomass and quality of the seedlings; higher doses of biochar reduced the seedlings quality.

The Yellow variety responded better than the Hales Best Jumbo to the biochar application.

Considering the advantages of poultry litter biochar on the substrate constitution, its utilization constitutes a viable alternative for the development of the melon seedlings and for the environmental disposal of the poultry litter.

\section{Acknowledgements}

To the Coordination for the Improvement of Higher Education Personnel-CAPES for granting scholarships to the first author. 


\section{Conflicts of Interest}

The authors declare no conflicts of interest regarding the publication of this paper.

\section{References}

[1] Figueiredo, M.C.B., Gondim, R.S. and De Aragao, F.A.S. (2017) Produção de melão e mudanças climáticas: Sistemas conservacionistas de cultivo para redução das pegadas de carbono e hídrica. Embrapa Agroindústria Tropical-Livro técnico (INFOTECA-E).

http://ainfo.cnptia.embrapa.br/digital/bitstream/item/163048/1/OLV17001.pdf

[2] FAO (2019) Food and Agriculture Organization of the United Nations. Crops. 2014. http://faostat.fao.org/site/567/DesktopDefault.aspx?PageID=567\#ancor

[3] Nascimento, C.W.A., De Souza Nunes, G.H., Preston, H.A.F., Da Silva, F.B.V., Preston, W. and Loureiro, F.L.C. (2020) Influence of Silicon Fertilization on Nutrient Accumulation, Yield and Fruit Quality of Melon Grown in Northeastern Brazil. Silicon, 12, 937-943. https://doi.org/10.1007/s12633-019-00187-5

[4] Nadai, F.B., Menezes, J.B.D.C., Rodrigues, H.C., Catão, M., Advíncula, T. and Costa, C.A. (2015) Produção de mudas de tomateiro em função de diferentes formas de propagação e substratos. Revista Agroambiente, 9, 261-267. https://doi.org/10.18227/1982-8470ragro.v9i3.2348

[5] Zeist, A.R., Resende, J.T.V.D., Giacobbo, C.L., Faria, C., Rios, M.D. and Dias, D.M. (2017) Graft Takes of Tomato on Other Solanaceous Plants. Revista Caatinga, 30, 513-520. https://doi.org/10.1590/1983-21252017v30n227rc

[6] Pelloso, M.F., Farias, B.G.A.C. and De Paiva, A.S. (2020) Produção de mudas de meloeiro em substrato a base de ramas de mandioca submetido a diferentes períodos de compostagem. Colloquium Agrariae, 16, 87-100. https://doi.org/10.5747/ca.2020.v16.n1.a351

[7] Farias, G.A., Costa, A.C., Costa, S.F., Farias, G.A., Pereira, P.H.F. and Junior, L.F.C. (2019) Produção de mudas de maracujazeiro amarelo em substratos contendo resíduos vegetais. Colloquium Agrariae, 15, 141-148. https://doi.org/10.5747/ca.2019.v15.n1.a278

[8] Silva, R.V., Rodrigues, L.A., Silva, M.G., Silva, B.G. and Martins, M.A. (2019) Biochar and Mucuna Increase Papaya Plant Growth and Nutrition, as Well as Soil Fertility. Pesquisa Agropecuária Tropical, 49, 1-9. https://doi.org/10.1590/1983-40632019v4955210

[9] Costa, E., Jorge, M.H., Schwerz, F. and Cortelassi, J.D.S. (2013) Emergência E Fitomassa De Mudas De Pimentão Em Diferentes Substratos. Revista Brasileira De Ciências Agrárias, 8, 396-401. https://doi.org/10.5039/agraria.v8i3a2428

[10] Lehmann, J. and Joseph, S. (2009) Biochar for Environmental Management: An Introduction. In: Biochar for Environmental Management. Science and Technology, Earthscan, London, 1-12.

[11] Atkinson, C.J., Fitzgerald, J.D. and Hipps, N.A. (2010) Potential Mechanisms for Achieving Agricultural Benefits from Biochar Application to Temperate Soils: A Review. Plant and Soil, 337, 1-18. https://doi.org/10.1007/s11104-010-0464-5

[12] Raij, B.V. (2011) Fertilidade do solo e manejo de nutrientes. International Plant Nutrition Institute, Piracicaba.

[13] Chaves, L.H.G., Fernandes, J.D., Mendes, J.S., Dantas, E.B., Guerra, H.C., Tito, 
G.A., Silva, A.A.R., Laurentino, L.G.S., Souza, F.G., Lima, W.B. and Chaves, I.B. (2020) Characterization of Poultry Litter Biochar for Agricultural Use. Sylwan, 164, 468-487.

[14] Pereira, M.E., Varanda, L.D., Nakashima, G.T., Hansted, A.L.S., Silva. D.A., Tomeleri, J.O.P., Belini, G.B. and Yamaji, F.M. (2019) Caracterização da biomassa de cama de frango para fabricação de biochar. Revista Virtual de Química, 11, 1330-1343. https://doi.org/10.21577/1984-6835.20190092

[15] Jeffery, L.S., Verheijen, F.G.A., Van Der Velde, M. and Bastos, A.C. (2011) A Quantitative Review of the Effects of Biochar Application to Soils on Crop Productivity Using Meta-Analysis. Agriculture, Ecosystems and Environment, 144, 175-187. https://doi.org/10.1016/j.agee.2011.08.015

[16] Teixeira, P.C., Donagemma, G.K., Fontana, A. and Teixeira, W.G. (2017) Manual de métodos de análise de solo. 3rd Edition, rev. e ampl. Embrapa, Brasília.

[17] BRASIL (2014) Manual de métodos analíticos oficiais para fertilizantes minerais, orgânicos, organominerais e corretivos. Ministério da Agricultura, Pecuária e Abastecimento. Secretaria de Defesa Agropecuária. Coordenação Geral de Apoio Laboratorial, Murilo Carlos Muniz Veras (Org.)—Brasília: MAPA/SDA/CGAL.

[18] ASTM International ASTM D1762-84 (2007) Standard Test Method for Chemical Analysis of Wood Charcoal. ASTM International, West Conshohocken, 1-2.

[19] Medeiros, M.B.C.L., Jesus, H.I., Santos, N.F.A., Melo, M.R.S., Souza, V.Q., Borges, L.S., Guerreiro, A.C. and Freitas, L.S. (2018) Índice de Qualidade de Dickson e característica morfológica de mudas de pepino, produzidas em diferentes substratos alternativos. Agroecossistemas, 10, 159-173.

https://doi.org/10.18542/ragros.v10i1.5124

[20] Dickson, A., Leaf, A.L. and Hosner, J.F. (1960) Quality Appraisal of White Spruce and White Pine Seedling Stock in Nurseries. Forest Chronicle, 36, 10-13. https://doi.org/10.5558/tfc36010-1

[21] Ferreira, D.F. (2011) Sisvar: A Computer Statistical Analysis System. Ciência Agrária, 35, 1039-1042. https://doi.org/10.1590/S1413-70542011000600001

[22] Sparks, D. (2003) Environmental Soil Chemistry. Academic Press, San Diego. https://doi.org/10.1016/B978-012656446-4/50001-3

[23] Lucchini, P., Quilliam, R.S., Deluca, T.H., Vamerali T. and Jones, D.L. (2014) Does Biochar Application Alter Heavy Metal Dynamics in Agricultural Soil. Agriculture, Ecosystems \& Environment, 184, 149-157. https://doi.org/10.1016/j.agee.2013.11.018

[24] Fernandes, J.D., Chaves, L.H.G., Da Silva Mendes, J., De Brito Chaves, I. and Tito, G.A. (2018) Soil Chemical Amendments and the Macronutrients Mobility Evaluation in Oxisol Treated with Biochar. Journal of Agricultural Science, 10, 238-247. https://doi.org/10.5539/jas.v10n10p238

[25] Ayers, R.S. and Westcot, D.W. (1991) A qualidade da água de irrigação na agricultura. UFPB, Campina Grande.

[26] Silva, L.J.B., Cavalcante, A.S.S. and Araújo Neto, S.E. (2009) Produção de mudas de rúcula em bandejas com substratos a base de resíduos orgânicos. Ciência e Agrotecnologia, 33, 1301-1306. https://doi.org/10.1590/S1413-70542009000500015

[27] Zanetti, M., Cazetta, J.O., Mattos Júnior, D.D. and Carvalho, S.A.D. (2003) Uso de subprodutos de carvão vegetal na formação do porta-enxerto limoeiro "Cravo" em ambiente protegido. Revista Brasileira de Fruticultura, 25, 508-512.

https://doi.org/10.1590/S0100-29452003000300037 
[28] Silva, I.C.B.D., Fernandes, L.A., Colen, F. and Sampaio, R.A. (2017) Growth and Production of Common Bean Fertilized with Biochar. Ciência Rural, 47, e20170220. https://doi.org/10.1590/0103-8478cr20170220

[29] Tito, G.A., Chaves, L.H.G., Dantas, E.R.B., Laurentino, L.G.S., Souza, F.G. and Guerra, H.O.C. (2020) Biochar on Soil Chemical Properties and Beak Pepper (Capsicun chinense) Production. Agricultural Sciences, 11, 1133-1142. https://doi.org/10.4236/as.2020.1112074

[30] Bohara, H., Dodla, S., Wang, J.J., Darapuneni, M., Acharya, B.S., Magdi, S. and Pavuluri, K. (2019) Influence of Poultry Litter and Biochar on Soil Water Dynamics and Nutrient Leaching from a Very Fine Sandy Loam Soil. Soil and Tillage Research, 189, 44-51. https://doi.org/10.1016/j.still.2019.01.001

[31] Petter, F.A., Andrade, F.R., Junior, B.H.M., Gonçalves, L.G.V. and De Souza, T.R.S. (2012) Biochar como condicionador de substrato para a produção de mudas de eucalipto. Revista Caatinga, 25, 44-51.

[32] Galvão, J.R., De Almeida, K.C., Da Costa Carréra, L., Lima, L.M., Pacheco, M.J.B., De Assis, L.F.C.T., De Jesus, A.M.B.S., Carrera, J.C. and Viana, T.C. (2020) Adubação química e orgânica associados ao biocarvão promovem maior crescimento à chicória (Eryngium foetidum L.). Brazilian Journal of Development, 6, 19599-19611. https://doi.org/10.34117/bjdv6n4-213

[33] Silva, L.F.V., De Melo, E.I. and Gonçalves, P.A.S. (2019) Biocarvao de serragem de eucalipto como condicionador de substratos para produção de mudas de alface. Agri-Environmental Sciences, 5, 243-250. https://doi.org/10.36725/agries.v5i0.1614

[34] Petter, F.A., Junior, B.H.M., Andrade, F.R., Schossler, T.R., Gonçalves, L.G. and Marimon, B.S. (2012) Biochar como condicionador de substrato para a produção de mudas de alface. Agrarian, 5, 243-250.

[35] Souchie, F.F., Marimon Junior, B.H., Petter, F.A., Madari, B.E., Marimon, B.S. and Lenza, E. (2011) Carvão pirogênico como condicionante para substrato de mudas de Tachigali vulgaris LG Silva \& HC Lima. Ciência Florestal, 21, 811-821. https://doi.org/10.5902/198050984526

[36] Peixoto, C.P., Cruz, T.V. and Peixoto, M.F.S.P. (2011) Análise quantitativa do crescimento de plantas: Conceitos e prática. Revista Enciclopédia Biosfera, 7, 51-76.

[37] Nunes, M.M. (2010) Carvão vegetal como componente de substrato para produção de mudas de castanheira-do-Brasil (Bertholletia excelsa HB K.) Embrapa Amazônia Ocidental-Tese/dissertação.

[38] Mendes, N.V.B., Lima, D.D.C., Corrêa, M.D.M. and Natale, W. (2018) Emergence and Initial Development of Bacabeira in Different Substrates and Environments. Revista Brasileira de Agropecuária Sustentável, 8, 90-99.

https://doi.org/10.21206/rbas.v8i2.503

[39] Melo, R.M., Vieira, M.D.C., Carnevali, T.D.O., Gonçalves, W.V., Torales, E.P., Tolouei, S.E.L. and Santos, C.C. (2019) Calagem e textura do substrato afetam o desenvolvimento de Campomanesia adamantium (Cambess.) O. Berg. Revista de Ciências Agrárias, 42, 101-110.

[40] Hermann, R.K. (1964) Importance of Top-Root Ratios for Survival of Douglas-Fir Seedlings. Tree Planters Notes, 64, 7-11.

[41] Souza, G.K.A., Teixeira, W.G., Reis, R.A., Chaves, F.C.M. and Xavier, J.J.B.N. (2006) Growth of Crajiru (Arrabidaea chica Verlot.) on Different Growing Media. Revista Brasileira de Plantas Medicinais, 8, 62-65.

[42] Cecco, R.M., Klosowski, E.S., Silva, D.F. and Villa, F. (2018) Germinação e 
crescimento inicial de mudas de espécies não convencionais de fisális em diferentes substratos e ambientes. Revista de Ciências Agroveterinárias, 17, 45-53.

https://doi.org/10.5965/223811711712018045

[43] Trazzi, P.A., Higa, A.R., Dieckow, J., Mangrich, A.S. and Higa, R.C.V. (2018) Biocarvão: Realidade e potencial de uso no meio florestal. Ciência Florestal, 28, 875-887. https://doi.org/10.5902/1980509832128

[44] Hunt, G.A. (1990) Effect of Styroblock Design and Copper Treatment on Morphology of Conifer Seedlings. Proceedings of Target Seedling Symposium, Roseburg, August 1990, 218-222.

[45] Lin, K.-H., Wu, C.-W. and Chang, Y.-S. (2019) Applying Dickson Quality Index, Clhorophyll Fluorescence, and Leaf Area Index for Assessing Plant Quality of Pentas lanceolata. Notulae Botanicae Horti Agrobotanice, 47, 169-176.

https://doi.org/10.15835/nbha47111312 